\title{
POLYPARADIGMATIC STATUS OF THE COMMUNICATIVE CATEGORY OF ALTERITY
}

\author{
Evgeniya Yu. Kislyakova \\ Volgograd State Social Pedagogical University, Volgograd, Russia
}

\begin{abstract}
The article is focused on the issue of alterity in the context of contemporary communicative and cultural processes. The research is enhanced by the necessity to establish methodological grounds of the communicative category of alterity within scientific linguistic frames of cognitive linguistics, ethnopsycholinguistics, social linguistics, semiotics, emotive linguistics, linguistic ecology, thus introducing an innovative complementary theoretical base of alterity as a category of linguistics. The lingvophilosophical approach to the problem reveals the polyparadigmatic status of the category under scrutiny that is defined as a many-aspect phenomenon, as well as identifying a number of its aspects - parameters (e.g.: singularity - plurality; similarity - difference; standard nonstandard; definiteness - nondefiniteness, etc.) and their correlation with functions of communication (e.g.: pragmatic, orienting, adapting and others), which makes ground for the supposition that alterity in its parameters and the functions of communication are interdependable notions. The theoretical significance of the research is manifested in the fact that the parametres of alterity as a category enhance more precise interpretation of the latter in communicative situations which contain a certain number of specifiers to be defined in order to improve the lexicographical aspect of the phenomen as well as some issues in theory and practice of communication including solutions to geopolitical and social problems.
\end{abstract}

Key words: communicative category, alterity, functions of communication, I-concept, Alter-concept, semiosis, interpretation.

Citation. Kislyakova E.Yu. Polyparadigmatic Status of the Communicative Category of Alterity. Vestnik Volgogradskogo gosudarstvennogo universiteta. Seriya 2, Yazykoznanie [Science Journal of Volgograd State University. Linguistics], 2017, vol. 16, no. 4, pp. 243-254. (in Russian). DOI: https://doi.org/10.15688/jvolsu2.2017.4.24

УДК 81:1

Дата поступления статьи: 18.07.2017

ББК $81 \mathrm{~B}$

Дата принятия статьи: 15.09.2017

\section{ПОЛИПАРАДИГМАЛЬНЫЙ СТАТУС КОММУНИКАТИВНОЙ КАТЕГОРИИ ИНАКОСТИ}

\section{Евгения Юрьевна Кислякова}

Волгоградский государственный социально-педагогический университет, г. Волгоград, Россия

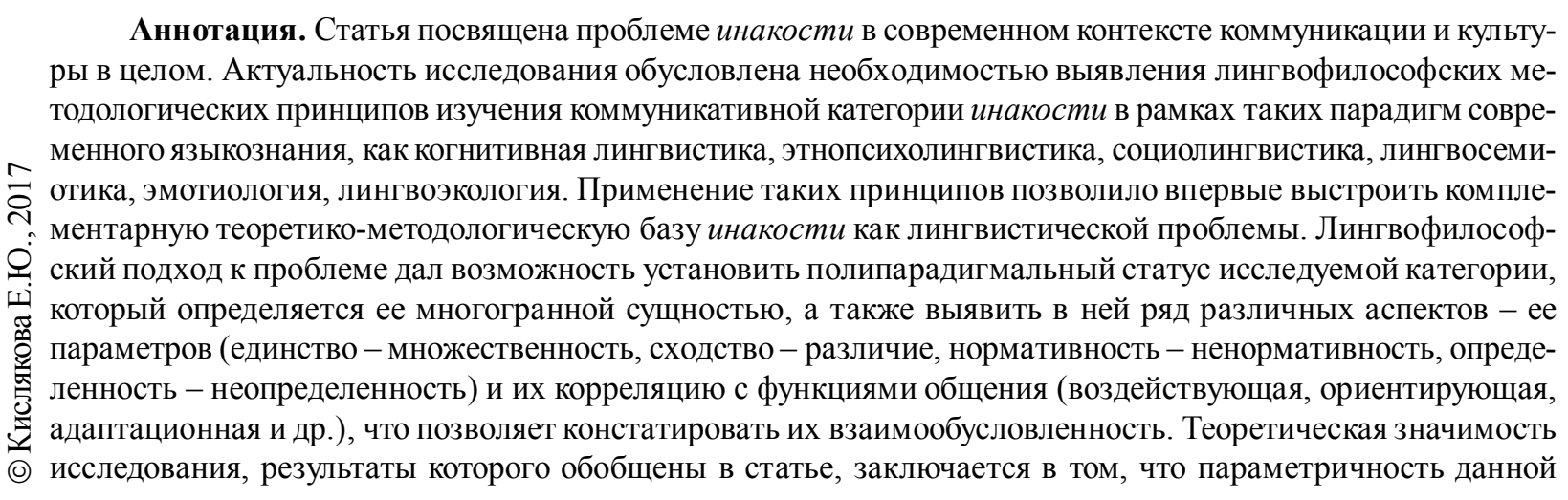


категории позволяет с большей точностью констатировать актуализацию инакости в коммуникативных ситуациях, в которых необходимо определить ее конкретизаторы с целью совершенствования лексикографии, теории и практики общения, а также решения геополитических и социальных проблем.

Ключевые слова: коммуникативная категория, инакость, функции общения, Я-образ, Ино-образ, семиозис, интерпретация.

Цитирование. Кислякова Е. Ю. Полипарадигмальный статус коммуникативной категории инакости // Вестник Волгоградского государственного университета. Серия 2, Языкознание. - 2017. - Т. 16, № 4. C. 243-254. - DOI: https://doi.org/10.15688/jvolsu2.2017.4.24

Чтобы осознать реальность, привычную для другого, вначале необходимо освободиться от собственной реальности; но человеку совсем не просто избавиться от привычной картины мира, эту привычку необходимо сломать силой.

Карлос Кастанеда

1

В лингвистике, как и в каждой области знания, сложилась традиция рассмотрения любого предмета исследования с позиции философии, дающей общее видение мира. Для лингвистического исследования методологически значимой является мысль М. Минского о том, что метафоры и аналогии «дают нам возможность увидеть какой-либо предмет или идею как бы “в свете” другого предмета или идеи, что позволяет применить знание и опыт, приобретенные в одной области, для решения проблем в другой области» [Минский, 1988, c. 291]. Таким образом, перед нами стоит задача «прочитать философские тексты глазами лингвиста» [Сковородников, 2014, с. 141] с целью выявления общеметодологических основ для разработки научной проблемы инакости как коммуникативной категории.

Инакость - одно из центральных понятий гуманитарной мысли XX-XXI веков. Выдающийся исследователь Ю.М. Лотман охарактеризовал 1990-е годы как временной период, когда «иное» окрасило «всю семиосферу в свой цвет и успело застыть и стать объектом усиленных теоретизирований на метакультурном уровне» [Лотман, 2000, с. 260]. Проблема Другого и, следовательно, его инакос$m u$, выйдя за пределы сугубо философского дискурса, стала объектом изучения других научных направлений.

Поскольку интерпретация инакости в сугубо лингвистическом плане должна осуще- ствляться в рамках имеющейся методологической базы, представляется целесообразным рассмотреть данную проблему с различных лингвофилософских позиций, отраженных в парадигмах современного языкознания (этнопсихолингвистика, когнитивная лингвистика, лингвосемиотика, лингвокультурология и т. д.). Следует подчеркнуть, что рассматриваемые в данной статье научные точки зрения выступают в качестве комплементарных теоретических основ инакости как лингвистической проблемы и в своей совокупности показывают многогранную природу исследуемого явления, которая обусловливает параметричность данной категории, а следовательно, возможность ее более точного выявления в актах коммуникации и определения конкретизаторов с целью совершенствования лексикографии, теории и практики общения, а также решения геополитических и социальных проблем (например, межэтнических конфликтов, создания текстов экстремистского характеpa, основанных на унижении культуры, веры, языка, пола, нации, расы Другого).

2

Во второй половине XX в. основными характеристиками сознания стали междисциплинарность, гибкость, мобильность, полиидентичность. Мир сегодня является системой без четко выраженной иерархии. Такие современные социальные тенденции, как изменчивость, неопределенность, децентрация, плюрализм и пр., свидетельствуют о том, что «гетерогенность пронизывает все важные события жизни и сознание людей. В такой ситуации именно различие становится основным фактором современной жизни, но различие не как простое несходство составляющих компонентов многообразия, а как активное взаимодействие позиций, ценностей, идей» [Половцев, 2008, с. 15]. 
Это общенаучное утверждение находит отражение и в языковых процессах. По мнению известного философа и лингвиста Г. Гийома, в многообразном диахроническом изображении все время встречается отношение всеобщее / единичное. Так, в глубинах человеческого разума, всех его умозаключений происходит ассимиляция универсальной мысли с мыслью человеческой. Применительно к лингвистике данный тезис следует понимать как отношение универсализации к сингуляризации [Гийом, 1992]. Например, форма артикля $a$ / an в английском языке указывает на одно из проявлений множественных подобий или аналогий, тем самым артикль сегментирует реальность (универсум) на отдельные понятия, которыми оперирует языковое сознание.

Научное мнение, аналогичное позиции Г. Гийома, высказывает такой известный лингвист и философ, как К. Ясперс, утверждая, что язык абсолютно необходим затем, чтобы сообщить наши мысли другим. При этом центральное место в употреблении языка он отводит Всеобъемлющему: «Язык есть постоянное прояснение из глубин активно действующего Всеобъемлющего, из жизни всех проявлений Всеобъемлющего. Подлинный язык сохраняет качество бесконечности означивания, которую он носит в себе и которая выражает себя в нем» [Ясперс, 1995, с. 195].

Данное утверждение позволяет обнаружить инаковую природу мира действительного в его языковом преломлении: предмет может оставаться одним и тем же в реальном мире, но в мире, смоделированным языком, он постоянно может меняться, поскольку меняется восприятие и понимание этого предмета. К. Ясперс по этому поводу пишет следующее: «Предмет осознается нами как нечто наличное не через произвольный выбор знаков, но через акт выражения, созидающий язык. Этот предмет больше не является голым “нечто”, но превращается в акт духа, внутреннее действие, внутренний опыт, способный к воспроизведению, знание о Всеобъемлющем и трансцендентном» [Ясперс, 1995, с. 196].

Следовательно, в концепции К. Ясперса признается многообразие языкового смысла как порождение Всеобъемлющего: язык признан пространством Всеобъемлющего; в качестве носителя идей он есть субстанциональная жизнь народного языка, в лично-экзистенциальном качестве он становится непереводимо-единичным. Выводом из вышесказанного является суждение об уникальности каждой языковой личности. Сопоставление всех таких «уникальностей» позволяет обнаружить искомую величину инакости.

Рассуждая о проблеме интерпретации смысла, Николай Кузанский в своей философской теории указывает на ключевую роль $и н а$ кости в понимании единичного. Философ считает, что единство каждой области поглощено континуумом инакости таким образом, что оно не может существовать в простой абсолютности само по себе из-за недостатка актуальности. Соответственно, соединение элементов неразложимо на простые элементы: разложение до простого начала дойти не может, да и сам простой элемент лишен способности актуального существования [Кузанский, 1979]. При этом Кузанский проводит сравнение с буквами, слогами, речью. Буквы и слоги сами по себе не имеют смысла, который возникает в самой речи.

Далее философ пишет о первичной и универсальной природе во всем во Вселенной, во всех ее дискретных элементах - бесконечности, представляющей собой единство (unitas), развертываемое во всех элементах мира, при сопоставлении которых наблюдается многообразие, различие (alteritas). Другими словами, инакость есть всегда и во всем проявление общего Сверхъединого. Поэтому ключевой в теории Н. Кузанского является идея двусторонности языковой единицы: признается ее одновременное вхождение в континуум инакости и наличие в ней как единстве внутреннего континуума (единство одного элемента заключается в актуальности других и собственная суть всякого элемента есть состав из элементов). Исходя из этого мы трактуем интерпретацию как процесс «перетекания» одного в другое в силу того, что они (одно и другое) составляют грани единого сверхсмысла, и, на наш взгляд, этот процесс бесконечен, поскольку он - «смысловой круговорот», на каждом этапе которого раскрывается иная интерпретанта. 
Исходя из вышесказанного у инакости как категории, проявляющей себя в коммуникации, можно выявить ориентирующую функцию: в процессе общения собеседники ориентируются друг на друга, выстраивая свое речевое взаимодействие (как конструктивное, так и деструктивное) с опорой на ситуативно приобретаемое понимание как себя, так и Другого. У М.М. Бахтина Другой имеет способность компенсировать и дополнять ограниченное видение Я («вненаходимость» и «избыток видения» Другого по отношению к позиции Я). С учетом субъектно-субъектных отношений Я и Другого (подробно об этом см.: [Кислякова, 2012]) считаем возможным дополнить данный тезис следующим утверждением: как Я достраивается смысловыми структурами, порождаемыми Другим, так и содержание Другого может дополняться с позиции Я.

Если у М.М. Бахтина Я и Другой взаимообусловлены, то Ж.-П. Сартр полагает, что человек стремится к тому, чтобы Другой признал факт его свободы. Философ видит ущербность человека именно в существовании Другого, поскольку человек воспринимает Другого как овеществление, отчуждение собственных возможностей. Такой антогонизм объясняется тем, что Другой как субъект претендует наравне с Я на то, чтобы быть центром мира. [Сартр, 2000, с. 278]. Следовательно, по Ж.-П. Сартру, Другой - это тот, кто дезинтегрирует мой мир: «Появление среди объектов моего универсума элемента дезинтеграции этого универсума я и называю появлением определенного человека в моем универсуме» [Сартр, 2000, с. 278].

Под взглядом Другого Я становится объектом, но и Другой становится объектом под взглядом Я. Отсюда выводится воздействующая функция инакости, имеющая место в коммуникации (социально-статусное распределение ролей, дающее возможность манипулировать партнером и ходом коммуникации в целом). Например, опасность в интерпретации Ж.-П. Сартра представляет собой такую ситуацию, когда под взглядом Другого субъект ощущает, что тот владеет им: «это владение есть не что иное, как сознание обладания мной» [Сартр, 2000, с. 380]. Таким образом, для Сартра ситуация взаимодействия 
с Другим происходит в форме конфликта, причем конфликт неизбежен, так как отношения равенства, как считает Ж.-П. Сартр, невозможны: конфликт есть первоначальный смысл бытия-для-другого.

\section{4}

В разработке концепции Другого представляют интерес идеи таких постструктуралистов, как Ж. Лакан, Ж. Делез, которые видят связь между понятиями «желание» и «Другой». Человеческим желанием является желание Другого: человек склонен испытывать желание Другого там, где имеется конкуренция, соперничество, истоки которого кроются в моменте осознания себя как другого в процессе распознавания своего отражения в зеркале и узнавания своего желания в теле Другого (подробнее см.: [Лакан, 1997]).

Другой принадлежит к порядку Символического, к которому может быть отнесен язык. Ж. Лакан отмечает, что как только ребенок столкнется с Другим, он немедленно начинает защищаться от реальности посредством языка. Другой означает для него встречу с культурой. Поскольку Символическое, согласно Ж. Лакану, интериоризируется бессознательно, то Другой в процессе освоения символической составляющей культуры является инстанцией, которая контролирует наши способы вхождения в мир символов. Более того, человек всегда ищет себя через Другого, часто изобретая и Другого, и себя. В данном случае Я и Другой - это границы нормы, в рамках которых будет действовать индивид в той или иной культуре, поэтому категория инакости связана с понятиями нормативности и ненормативности.

Исследователь О.В. Рябов справедливо отмечает, что социальные границы выступают атрибутом социальности: процесс установления и корректировки социального порядка это и есть процесс проведения границ между дозволенным и недозволенным, между нормой и девиацией, между истинным и ложным, между Своими и Чужими [Рябов, 2012]. Из вышесказанного мы можем сделать вывод о том, что грани нормы являются границами, за пределами которых обнаруживается инакость, оцениваемая, как правило, негативно, поскольку категория нормативности выстраивается на основе собственных установок и правил поведения в своем окружении, будь то семья, профессиональная группа, социальный класс, социум, этнос в целом. Норма на каждом социальном уровне своя, следовательно, степень инакости будет варьироваться в зависимости от того, насколько грань нормы отдалена от индивидуальных этнопсихолингвистических восприятий.

Несколько по-иному рассматривает Другого Ж. Делез: Другой - это структура, делающая возможным мир и дающая шанс воспринимать объекты [Делез, 1998]. В концепции Ж. Делеза - два Других: «конкретный» Другой и «априорный» Другой. Важно подчеркнуть, что один Другой не исключает другого Другого, ибо «априорный» Другой обеспечивает существование возможного мира вообще, несет в себе саму возможность этого мира как таковую, а «конкретный» Другой выражает реальные элементы и актуализирует структуру возможного мира. Следовательно, возможное может стать реальным, когда оно выражено, актуализировано. Таким образом, категория Другого и категория возможного взаимообусловлены, и актуализация одной из категорий в языке свидетельствует об актуализации второй (например, в модальных конструкциях, в формах сослагательного наклонения). Этот тезис указывает на такой параметр инакости, как гипотетичность.

\section{5}

В постнеклассический период науки складывается такое понимание Другого, при котором инакость приобретает большую значимость, нежели Я как субъект. Трансмодернизм фиксирует смещение акцента с модуса изъявительного наклонения в модус сослагательного. Философия Эпштейна объясняет это как возможность обладания невозможным (например, социально-экономически это проявляется в возможности повышать свой материальный уровень за счет системы кредитования) [Эпштейн, 2001].

Сегодня есть все основания полагать, что у современного человека представления о мире в значительной степени обусловлены не свободной творческой активностью, а со- 
циумом, последовательно навязывающим определенные идеи и намеренно тормозящим индивидуальную познавательную деятельность посредством различных видов дискурсивных практик (масс-медийного жанра, в первую очередь). Иными словами, человеческая личность сочетает в себе в той или иной степени личности всех взаимодействующих с ним индивидов, социальных групп, общества в целом (наиболее яркий пример - это растворение личности в киберпространстве социальных сетей). В этой связи мы хотели бы указать на такую проблему инакости, как Ино-образ [Кислякова, 2017] языковой личности и распознавание в нем собственно Я-образа, а также размывание границ идентификации и самоидентификации личности.

С точки зрения когнитивной науки проблема Другого сопряжена с проблемой концептуализации и категоризации пространственно-дейктических, социально-культурных и индивидуально-психологических параметров общения. Другой является пространством, в котором происходит осознание феномена «Я». Без инакости Другого представляется невозможным выработать систему различий «Я не Я», «свой - чужой», «Мы - Они» и др. Другой определяет не только наше существование в целом, но и пространство, и время нашего существования, что на языковом уровне выражается следующими формами пространственного и временного дейксиса: «здесь - там», «этот - тот», «сейчас - тогда», «сейчас - потом, затем».

По мнению А.В. Кравченко, суть коммуникации состоит в оказании одним организмом ориентирующего воздействия на другой организм [Кравченко, 2001]. В основе этого утверждения видится значимый статус инакости как категории коммуникации, поскольку в результате такого ориентирующего воздействия поведенческая реакция ориентируемого организма подвергается модификации. При этом воздействие одного организма на другой является интенциональным актом, так как направлено на выживание экзистенциальный приоритет живой системы. Присутствие Другого задает адаптивные возможности языка как знаковой системы и обусловливает каузальные отношения между сущностями: взаимодействие с одной сущностью ведет к взаимодействию с другой и наоборот.

Каузальная связь между двумя сущностями существует в виде сложной репрезентации, инкорпорирующей элементарные репрезентации этих взаимодействий. Вытекая из природы отношений одного и другого, взаимодействия между сущностями, в том числе знаковыми, взаимно каузальны: как слово может служить знаком одного объекта, так и объект может служить знаком слова. Для данного исследования методологически значимым выводом из сказанного выше является тот факт, что изучение инакости должно включать сопоставление ее свойств и характеристик с той лингвокогнитивной сферой, на фоне которой прослеживается их активность.

Кроме этого, понимание Другого как средства адаптации и выживания в коммуникативной среде позволяет присвоить категории инакости экзистенциальный статус, а адаптивную функцию языка считать реализуемой как при явной, так и при имплицитной актуализации категории инакости в общении.

В лингвокультурологическом аспекте наибольшую ценность для понимания инакости представляет тезис В. фон Гумбольдта о «языковом мировидении»: разные языки это не различные звуковые обозначения одного и того же предмета, а «различные видения» его. Хотя в повседневной практике это мировидение зачастую остается невидимым, оно, по мнению В.В. Красных, ощутимо проявляется и становится заметным, когда носитель культуры сталкивается с иным, другим, чужим и чуждым [Красных, 2012], поскольку, как отмечает проф. Е.Ф. Тарасов, языковое сознание представляет собой опосредованный языком образ мира собственной культуры, то есть «совокупность перцептивных, концептуальных и процедурных знаний носителя культуры об объектах реального мира» [Тарасов, 1996, с. 187]. Следовательно, в прикладном аспекте проблема инакости - это проблема того, как общаться друг с другом, в особенности на другом языке, с учетом адекватной трансляции инакости одной лингвокультуры в другую.

В этой связи Н.В. Уфимцева указывает на то важное обстоятельство, что превосходство собственной культуры выглядит есте- 
ственным для обыденного сознания, «чужое» же представляется странным, неестественным, уклонением от единственно правильного образа жизни, свойственного собственной культуре [Уфимцева, 1998]. Психолингвистические исследования, проводимые в области языкового сознания, позволяют выделить структурообразующие элементы этнического бессознательного, то есть константы, через которые человек видит окружающий мир [Уфимцева, 2000]. В целом поддерживая мнение Н.В. Уфимцевой, мы считаем, что сопоставление различных этносов с целью объективации категории инакости в межкультурной коммуникации должно выстраиваться с опорой на такие базовые ментальные структуры, своеобразные психоэтноязыковые «фильтры», которые, накладываясь друг на друга, будут демонстрировать степень и интенсивность инакости, проявляющейся в общении.

Таким образом, категория инакости помещается во главу угла при изучении процессов межкультурного общения, поэтому феноменологически инакость не может быть описана в условиях опущения лингвоэтнокультурной специфики языкового материала.

\section{6}

Идея «языкового мировидения» плодотворна для осознания более глубоких основ коммуникации. Мы считаем, что следующее рассуждение В. фон Гумбольдта иллюстрирует актуальность категории инакости не только на межэтническом уровне, но также в рамках одного языкового социума: «Люди понимают друг друга не потому, что передают собеседнику знаки предметов, и даже не потому, что взаимно настраивают друг друга на точное и полное воспроизведение идентичного понятия, а потому, что взаимно затрагивают друг в друге одно и то же звено цепи чувственных представлений и начатков внутренних понятий, прикасаются к одним и тем же клавишам инструмента своего духа, благодаря чему у каждого вспыхивают в сознании соответствующие, но не тождественные смыслы» [Гумбольдт, 2001, с. 84]. В интерпретации фон Гумбольдта все, что нетождественно, - инако, отсюда и различие в мировидении и смыслопорождении.
Эта проблема своими корнями уходит в саму природу языкового знака. Так, в рамках московской психолингвистической школы было экспериментально установлено, что процесс денотации не полностью предопределяется значением знака. Отсюда следует, что денотаты слова в речи одного говорящего могут не совпадать с его денотатами в речи другого говорящего. Например, то, что один назовет родным, может оказаться чуждым для другого [Бубнова, Клименко, 2016].

В аспекте семиотики проблема инакос$m и$ произрастает из знакового принципа «Чтото стоит вместо чего-то». У. Эко поднимает вопрос о возможности отделения антецедента, возникающего в речи, от самой речи, которая его представляет. Согласно его мнению отношение, существующее между фактом, пропозицией, которая его представляет, и высказыванием, выражающим эту пропозицию, неразрывно. Тем не менее в языке работает способ «быть вместо», то есть коммуникант имеет дело со своеобразной диалектикой присутствия и отсутствия. Именно поэтому многогранность языкового знака выводит последний в интерпретациях философа из системы значения: «... это единица, узнаваемая из процесса коммуникации» [Eco, 1988, p. 30] (здесь и далее перевод с французского наш. $-E$. K.).

Уникальная природа знака указывать на другое порождает проблему соотношения плана выражения и плана содержания. Таким образом, семиотическая функция возникает на основе диалекти присутствия и отсутствия. При этом, по определению Ю. Кристевой, знак сводит различающиеся инстанции к совокупному единству и отношение, которое устанавливает знак, выглядит как согласование отклонений, отождествление различий [Кристева, 2004]. Данное понимание знака опровергается У. Эко на основе философии Иного, аргументы которой приводятся ниже.

Категориально инакость раскрывается в знаковой природе в возможности интерпретации, которая сама по себе предполагает множественность смыслопорождений. Интерпретируемое содержание заставляет идти дальше, за пределы изначального знака, что позволяет осознать обязательность присутствия в будущем контексте другого знака. Исследователь справедливо замечает, что 
знак - это всегда то, что открывает во мне нечто другое, мое другое Я. Не существует интерпретирующего, который бы, проясняя содержание интерпретируемого знака, не сместил бы, хоть не намного, его границ. Поэтому бесперспективна мысль о замещении подобного подобным в процессе семиозиса.

Диалектика «Я» и «Другого» в процессе семиозиса сконцентрирована в знаке: «Если знак как равенство и тождество был соотносим с застывшим (и идеологическим) понятием субъекта, то как момент (всегда кризисный) процесса семиозиса знак - это инструмент, с помощью которого субъект извечно созидает и разбирает самого себя <...> Субъект является тем, что сделали из него длительные процессы ресегментации содержания. Как субъекты, мы являемся тем, что из нас сделала форма мира, созданная знаками» [Есо, 1988, p. 62].

Схожая с изложенной точка зрения на слово как знак представлена в трудах П. Флоренского: философ указывает на изменчивость, непостоянность семемы слова и на отсутствие у нее какого-либо самостоятельного значения в отрыве от речи: «Семема слова непрестанно колышется, дышит, переливает всеми цветами и не имеет никакого самостоятельного значения, будучи уединенной от этой моей речи <...>. Скажи это слово ктонибудь другой, да и я сам в другом контексте - и семема его будет иная; мало того, более тонкие его слои изменятся даже при дословном повторение той же самой речи и даже тем же самым лицом <..> Слова неповторимы; всякий раз они говорятся заново, то есть с новой семемой, и в лучшем случае это бывает вариация на прежнюю тему. Объективно единым в разговоре бывает только внешняя форма слова, но никак не внутренняя» [Флоренский, 1998, с. 229].

Инакообразие объектов мира запечатлевается в языковой семантике, но его декодирование может быть бесконечно разнообразно. Говоря словами Гумбольдта, «никто не думает при известном слове именно того, что другой... Всякое понимание есть вместе непонимание, всякое согласие в мыслях - вместе несогласие» [Гумбольдт, 2001, с. 84].

В категориальной структуре инакости выделяется тип отношений Я - не-Я. П. Фло- ренский находит «мост» между этими сущностями в слове. Таким образом, мыслитель называет слово онтологической изотропой: «Слово есть познающий субъект и познаваемый объект, <..> это мост между Я и не-Я. $<\ldots>$ Мы чрез слово станем ввинчиваться вниманием в энергию сущности человека, познавая его, ибо слова его непосредственно дают нам его самодеятельность, а этою последнею раскрывается сокровенная его сущность. И мы уверены: слово есть сам говорящий. Напротив, рассматривая слово с берега Я, свое собственное слово, под углом психои гносеологии, мы можем и должны говорить о нем: «Вот она - познаваемая реальность, вот он - познаваемый объект» [Флоренский, 1998, с. 233]. В целом соглашаясь с исследовательскими позициями П. Флоренского, уточним, что слово и язык в общем как грань соприкосновения Я и не-Я запечатлевают признаки как одного, так и другого, но такие «оязыковленные слепки» имеют определенную степень аппроксимации, поскольку, наслаиваясь друг на друга, они дают усредненную языковую картину, в которой обязательно наличие наиболее ярких признаков, составляющих ядро инакости, и более периферийных, маргинальных.

7

Категория инакости в коммуникации может быть обусловлена категорией эмоционального. Так, известный философ Т. Гоббс, рассуждая об именах вещей, приходит к умозаключению, что «имена таких вещей, которые вызывают в нас известные эмоции, то есть доставляют нам удовольствие или возбуждают наше неудовольствие, имеют в обиходной речи непостоянный смысл, так как одна и та же вещь вызывает одинаковые эмоции не у всех людей, а у одного и того же человека не во всякое время» [Гоббс, 1991, с. 30].

Действительно, поскольку мы знаем, что все имена даются, чтобы обозначить наши представления, и что все наши аффекты суть тоже лишь представления, то, различно воспринимая одни и те же вещи, мы едва ли можем избежать различного их названия. Как утверждает Г. Гоббс, хотя природа воспринимаемого остается всегда одной и той же, тем 
не менее различие наших восприятий этой вещи накладывает на каждую вещь отпечаток наших различных эмоций. Именно поэтому, рассуждая, человек должен быть осторожен со словами, которые помимо значения, обусловленного природой представляемой при их помощи вещи, имеют еще значение, обусловленное природой, наклонностями и интересами говорящего. Таковы, например, имена добродетелей и пороков, так как то, что один человек называет мудростью, другой называет страхом; что один называет жестокостью, другой - великодушием; один - серьезностью, а другой - тупостью и т. П. Поэтому позиция интерпретатора - это только один из возможных вариантов интерпретации, который предполагает обязательное наличие множества иных интерпретаций с позиции Другого (Я-другого и другого Я).

Как утверждает В.И. Шаховский, когда люди общаются, они транслируют друг на друга свое миропонимание в образах и картинках и индуцируют соответствующие образы-картинки у своих коммуникативных партнеров [Шаховский, 2012, с. 71-80]. Естественно, что эти образы-картинки эмоционально окрашены. Их эмоциональность более голографична, чем эмоциональность слов, поскольку мы все различаемся по эмоциональному параметру. Данный тезис В.И. Шаховского представляется нам справедливым, поскольку, по нашему убеждению, если ratio нас в основном объединяет, то emotio может создавать предпосылки инаковой природы каждого коммуниканта. Поэтому степень аппроксимации образных представлений влияет на степень успешности вербальной эмоциональной коммуникации.

Кроме этого, для теории инакости ценной является идея В.И. Шаховского об адаптирующей роли языка в кооперативном общении в его соотношении с тьюнинг-функцией. Приспособление (настройка / тьюнинг) речевых партнеров друг к другу в прагматических целях приводит к взаимному коммуникативному успеху, поскольку их языковая адаптация к коммуникативному стилю друг друга формирует у них общий эмоционально-координационный центр и делает их общение гармоничным. Адаптация и тьюнинг соответствуют принципу кооперативности эмоционально- го общения, а также его продуктивности [Шаховский, 2012, с. 71-80]. Поэтому, говоря о категории инакости в терминах эмотивной лингвистики и эмотивной лингвоэкологии, невозможно обойти вниманием тот факт, что эмоции входят в категориальную структуру инакости, а также то, что данная категория взаимообусловлена параметром экологичности / неэкологичности общения.

\section{8}

Резюмируя вышеизложенные научные взгляды, можно выделить следующие общеметодологические основы теории инакости как коммуникативной категории:

1. Категория инакости по сути бинарна, так как включает значимое соотнесение одного с другим, при котором осознается общее и различное.

2. В языковом общении выявляется антиномия «универсального vs. единичного», которая предполагает проявление общего в индивидуальном; такое проявление общего в индивидуальном всякий раз различно. У каждой языковой личности язык как средство общения единичен и непереводим в разных дискурсивных условиях.

3. Вхождение индивида в культуру и в ее структуру символов (в том числе и в язык) осуществляется в категориальных рамках инакости, поскольку посредством Другого устанавливаются грани нормы, регулирующие вхождение в культуру (интериоризации) и деятельности в ней (экстериоризации).

4. Инакость как категория, раскрывающая отношения Я - Другой, определяет ориентирующую функцию общения, поскольку коммуникативное взаимодействие должно выстраиваться с опорой на контекстное понимание как себя, так и Другого. Другой выступает средством адаптации и выживания в коммуникативной среде, что позволяет присвоить категории инакости экзистенциальный статус, а адаптивную функцию языка считать реализуемой как при явной, так и при имплицитной актуализации категории инакости в общении.

5. Коммуникативная категория инакости является основополагающей как для внутреннего, так и внешнего диалога человека и, следовательно, настраивание человеком са- 
мого себя на кооперативное / деструктивное общение с другими. В связи с этим инакость квалифицируется как категория, смежная с экологичностью - неэкологичностью языка: именно инакость интегрирует основные сложности и проблемы коммуникации homo loquens и является одной из возможных причин снижения качества жизни человека.

6. Категория инакости проявляется в воздействующей функции общения, которая реализуется при неравноправном статусе коммуникантов, что возможно в том случае, когда либо Я, либо Другой воспринимаются как объекты, а не субъекты взаимодействия. Субъектно-объектный статус инакости определяет конфликтный характер коммуникации. В современном трансмодернистском понимании коммуникации категория инакости становится первостепенной по отношению к категории Я, ощущается растворенность Я в Другом, что приводит к постановке проблемы степени взаимообусловленности одного и другого, в частности, Ино-образа языковой личности и распознавания в нем собственно Я-образа, а также размывания границ идентификации и самоидентификации личности.

7. Постоянное соотношение одного и другого в рамках категории инакости объясняет бесконечную природу интерпретации смысла и процесса семиозиса. Понимание одного всегда осуществляется в системе Другого, во всех его проявлениях (когнитивно-концептуальном, эмоционально-оценочном, морально-этическом и пр.). Поскольку проблема понимания до сих пор остается главной проблемой современных гуманитарных наук, то привлечение методик психолингвистических исследований как раздела филологической герменевтики является неотъемлемой предпосылкой создания наиболее обоснованной концепции инакости.

Таким образом, категория инакости зиждется на методологических основах следующих парадигм современной лингвистики: лингвосемиотики, когнитивной лингвистики, социолингвистики, этнопсихолингвистики, эмотиологии и лингвоэкологии. При этом доминантными позициями, на которых должна строиться теория инакости, являются этно-, психо- и эмотивно-лингвистические аспекты, что, безусловно, требует дальнейшей верификации.

\section{СПИСОК ЛИТЕРАТУРЫ}

Бахтин М. М., 1997. Работы 1940-х - начала 1960-х годов // Собрание сочинений : в 5 т. М. : Русские словари. Т. 5. С. 329-363.

Бубнова И. А., Клименко А. П., 2016. Психолингвистические проблемы семантики в постнеклассическую эпоху: новое знание как результат взаимодействия традиций и новаций // Вопросы психолингвистики. № 1. С. 60-70.

Гийом Г., 1992. Язык и его порождение // Принципы теоретической лингвистики. М. : Культуpa. C. $135-136$.

Гоббс Т., 1991. О человеке // Гоббс Т. Сочинения : в 2 т. М. : Мысль. Т. 2. С. 21-30.

Гумбольдт В. фон, 2001. О различии строения человеческих языков и его влиянии на духовное развитие человечества // Гумбольдт В. фон. Избранные труды по языкознанию. М. : ОАО ИГ «Прогресс». С. 37-298.

Делез Ж., 1998. Логика смысла / пер. с фр. Я. И. Свирского. М. : Раритет; Екатеринбург : Деловая кн. $480 \mathrm{c}$.

Кислякова Е. Ю., 2012. Проблема лексикографирования инакости и инаковости: уточнение понятий // European Social Science Journal. № 1. C. $183-190$.

Кислякова Е. Ю., 2017. Ино-образ в структуре языковой личности как проблема коммуникативистики // Известия Волгоградского государственного педагогического университета. № 2. C. 115-121.

Кравченко А. В., 2001. Знак, значение, знание. Очерк когнитивной философии языка. Иркугск : Изд. ОГУП. $260 \mathrm{c}$.

Красных В. В., 2012. Культурная идентификация и самоидентификация: взгляд филолога // Межэтническое общение: контакты и конфликты : сб. ст. / под ред. Н. В. Уфимцевой. М. : ИЯз РАН-МИЛ. С. 16-28.

Кристева Ю., 2004. Исследования по семанализу // Избранные труды: Разрушение поэтики : пер. с франц. М. : Российская политическая энциклопедия. С. 29-112.

Кузанский Н., 1979. Книга вторая // Избранные философские сочинения : в 2 т. М. : Мысль. Т. 1. C. $95-142$.

Лакан Ж., 1997. Стадия зеркала и ее роль в формировании функции // Инстанция буквы в бессознательном, или Судьба разума после Фрейда / пер. с фр. А. К. Черноглазова, М. А. Титовой. М . : Рус. феноменол. о-во. С. 7-14.

Лотман Ю. М., 2000. Семиосфера. СПб. : «Искусство-СПб». С. 250-296.

Минский М., 1988. Остроумие и логика когнитивного бессознательного / Пер. с англ. М. А. Дмит- 
ровской // Новое в зарубежной лингвистике. Вып. 23. Когнитивные аспекты языка. М. : Прогресс. С. 281-310.

Половцев Д. О., 2008. Проблема инаковости в творчестве Э.М. Форстера : дис. ... канд. филол. наук. Минск, 2008. 154 с.

Рябов О. В., 2012. Российскость vs. Русскость: семантика символических границ // Межэтническое общение: контакты и конфликты : сб. статей / под ред. Н. В. Уфимцевой. М. : ИЯз РАН-МИЛ. C. 6-15.

Сартр Ж.-П., 2000. Бытие и ничто: опыт феноменологической онтологии / пер. с фр. В. И. Колядко. М. : Республика. 693 с.

Сковородников А. П., 2014. К философским основаниям предметной области эколингвистики // Экология языка и коммуникативная практика [Ecology of Language and Communicative Practice]. № 2. C. 140-161.

Тарасов Е. Ф., 1996. Межкультурное общение новая онтология анализа языкового сознания // Этнокультурная специфика языкового сознания. М. : Российская Академия наук, Институт языкознания. С. 7-22.

Уфимцева Н. В., 1998. Этнический характер, образ себя и языковое сознание русских // Языковое сознание: формирование и функционирование : сб. ст. М. : Ин-т языкознания РАН. C. $135-170$.

Уфимцева Н. В., 2000. Языковое сознание и образ мира славян // Языковое сознание и образ мира: сб. ст. / отв. ред. Н. В. Уфимцева. М. : Ин-т языкознания РАН. С. 207-219.

Флоренский П., 1998. Имена: Сочинения. М. : «Фолио». С. 224-239.

Шаховский В. И., 2012. Голос эмоций в языковом круге homo sentiens. M. : URSS : Либроком. $141 \mathrm{c}$.

Эпштейн М., 2001. Философия возможного. СПб. : «Алетейя». С. 43-138.

Ясперс К., 1995. Язык // Философия языка и семиотика. Иваново : Ивановский ун-т. С. 190-202.

Eco U., 1988. Semiotique et Philosophie du Langage. P. : Presses Universitaire de France. P. 24-62.

\section{REFERENCES}

Bakhtin. M.M., 1997. Works of the 1940s - early 1960s. V. 5. Sobranie sochineniy. In 5 vol. [Set of Works. In Vol. 5]. Moscow, Russkie slovari Publ., pp. 329363. (in Russian).

Bubnova I.A., Klimenko A.P., 2016. Psycholinguistic issues of semantics in the post-nonclassic period: new knowledge as a result of tradition and innovation interaction. Voprosy psikholingvistiki
[Journal of Psycholinguistics], no. 1, pp. 60-70. (in Russian).

Giiom G., 1992. Language and its reproduction. Printsipy teoreticheskoy lingvistiki. Moscow, Kultura Publ., pp. 135-136. (in Russian).

Gobbs T., 1991. On the human-being. Sochineniya, vol. 2. Moscow, Mysl Publ., pp. 21-30. (in Russian).

Gumboldt W. fon, 2001. On the difference of the human languages structure and its influence on the spiritual development of humanity. Izbrannye trudy po yazykoznaniyu [Selected works on linguistics]. Moscow, Progress Publ., pp. 37-298. (in Russian).

Delez Zh., 1998. The logic of sense. Moscow, Raritet Publ.; Ekaterinburg, Delovye knigi Publ. 472 p. (in Russian).

Kislyakova E.Yu., 2012. The problem of dictionary representation of the Russian words inakost and inakovost: definition specification. European Social Science Journal, no. 1, pp. 183-190. (in Russian).

Kislyakova E.Yu., 2017. Alter-concept in the structure of the language personality as a communicative issue. Izvestiya Volgogradskogo gosudarstvennogo pedagogicheskogo universiteta [Izvestia of the Volgograd State Pedagogical University], no. 2, pp. 115-121. (in Russian).

Kravchenko A.V., 2001. Sign, meaning and knowledge. A sketch on the cognitive philosophy of the language. Irkutsk, OGUP Publ. 261 p. (in Russian).

Krasnykh V.V., 2012. Cultural identity and self-identity: a philological approach. Mezhetnicheskoe obshchenie: kontakty i konflikty. Moscow, IYaz RAN-MIL Publ., pp. 16-28. (in Russian).

Kristeva Yu., 2004. Research on semantic analysis. Izbrannye trudy: Razrushenie poetiki [Selected works: Deconstruction of poetics]. Moscow, Rossiyskaya politicheskaya entsiklopedia, pp. 29-112. (in Russian).

Kuzanskiy N., 1979. Book two. Izbrannye filosofskie sochineniya [Selected works on philosophy]. Moscow, Mysl Publ., vol. 1, pp. 95-142. (in Russian).

Lakan Zh., 1997. The stage of the mirror and its role in function forming. Instantsiya bukvy $v$ bessoznatelnom, ili Sudba razuma posle Freida. Moscow, Russian phenomenological society Publ., pp. 7-14. (in Russian).

Lotman Yu.M., 2000. Semiosphere. St. Petersburg, Iskusstvo Publ. 704 p. (in Russian).

Minskiy M., 1988. Quick-wittiedness and the logics of the cognitive subconscious. Novoe $v$ zarubezhnoy lingvistike. Vyp. 23. Kognitivnye aspekty yazyka. Moscow, Progress Publ., pp. 281-310. (in Russian). 
Polovtsev D.O., 2008. Problema inakovostiv tvorchestve E.M. Forstera [The issue of otherness in E.M. Forster's literary work]. Minsk, 2008. 154 p. (in Russian).

Ryabov O.V., 2012. Being Russian vs. a citizen of Russia: the semantics of symbolic borderlines. Mezhetnicheskoe obshchenie: kontakty $i$ konflikty. Moscow, IYaz RAN-MIL Publ., pp. 615. (in Russian).

Sartr Zh.-P., 2000. Being and nothing: an experiment in phenomenological onthology. Moscow, Respublika Publ. 693 p. (in Russian).

Skovorodnikov A.P., 2014. To the philosophical bases of subject domain of ecolinguistics. Ekologiya yazyka i kommunikativnaya praktika [The ecology of the language and the communication practice], no. 2, pp. 140-161. (in Russian).

Tarasov E.F., 1996. Crosscultural communication as a new onthology of analyzing the linguistic consciousness. Etnokulturnaya spetsifika yazykovogo soznaniya [Ethnocultural peculiarities of the linguistic consciousness]. Moscow, Rossiyskaya Akademiya Nauk, Institut yazykoznaniya, pp. 7-22. (in Russian).
Ufimtseva N.V., 1998. The ethnical character, mental self-representation and the linguistic consciousness of the Russians. Yazykovoe soznanie: formirovanie i funktsionirovanie [Linguistic consciousness: formation and functioning]. Moscow: Institut yazykoznaniya RAN, pp. 135-170. (in Russian).

Ufimtseva N.V., 2000. Linguistic consciousness and world representation of the Slavs. Yazykovoe soznanie i obraz mira. Moscow, Institut yazykoznaniya RAN, pp. 207-219. (in Russian).

Florenskiy P., 1998. Imena: Sochineniya [Names: Works]. Moscow, Folio Publ., pp. 224-239. (in Russian).

Shakhovskiy V.I., 2012. The voice of emotions in the language circle of homo sentiens. Moscow, Librokom Publ. 144 p. (in Russian).

Epshtein M., 2001. The philosophy of the possible. Saint Petersburg, Aleteya Publ. 366 p.

Yaspers K., 1995. Language. Filosofiya yazyka $i$ semiotika. Ivanovo, Ivanovovskiy Universitet Publ., pp.190-202. (in Russian).

Eco U., 1998. Semiotique et Philosophie du Langage. Paris, Presses Universitaire de France, pp. 24-62.

\section{Information about the Author}

Evgeniya Yu. Kislyakova, Candidate of Sciences (Philology), Associate Professor, Department of English Language and Teaching Technique, Volgograd State Socio-Pedagogical University, Prosp. Lenina, 27, 400066 Volgograd, Russia, kisjen@rambler.ru, http://orcid.org/0000-0001-6425-9829

\section{Информация об авторе}

Евгения Юрьевна Кислякова, кандидат филологических наук, доцент кафедры английского языка и методики его преподавания, Волгоградский государственный социально-педагогический университет, просп. им. В.И. Ленина, 27, 400066 г. Волгоград, Россия, kisjen@rambler.ru, http://orcid.org/0000-0001-6425-9829 